\title{
Digitalization of business processes of energy supply in a smart city
}

\author{
Irina Petrova, Viktoriya Zaripova, Tatiana Zolina and Yuliya Lezhnina* \\ Astrakhan State University of Architecture and Civil Engineering, Tatischeva Str., 18, 414056 \\ Astrakhan, Russia
}

\begin{abstract}
The key role in the energy supply efficiency of smart cities is played by the electric power industry. The article provides an overview of the challenges of the electricity market in Europe and Russia and its main trends and directions. Changes in the organizational structure of the market, the role and tasks of each body managing the selected area of activity in the energy market are determined. Particular attention is paid to new opportunities provided to end-users of electricity in the smart cities. The article deals with the use of renewable sources and energy storages in accordance with new strategic programs in the EU and Russia. The research results and forecasts for the development of the electricity market and the use of different primary energy sources are shown. The main areas of development of the electricity market in the European Union and Russia are identified.The conclusion is drawn on the need to develop information systems that meet market changes and the business functions of such systems are determined.
\end{abstract}

\section{Introduction}

In the framework of the program "Digital Economy of Russia [1]. one of the sections, "Smart City", is dedicated to the description of "innovative cities supporting technical solutions and organizational measures aimed at achieving the highest possible quality of resource management and the provision of services to create favorable conditions for living and business activity of the current and future generations."

The term "smart city" refers to a city that, on the basis of the widespread introduction of information and communication technologies, manages all related resources (urban infrastructure: transport, education, healthcare, energy resources, housing, and communal services, security, etc) to improve the quality of services provided to citizens and variety of their living environment [2,3].

Analysis of a number of studies on the development of "smart cities" [4-9] showed that the power industry plays a vital role in the effectiveness of such large-scale pro-jects, especially, the degree of its adaptation to the requirements of active consumers.

The introduction of smart-technologies provides a significant reduction in energy losses. It promotes environmental friendliness and efficient use of resources by improvingtechnologies for the production, delivery, and storage of electricity. It allows

${ }^{*}$ Corresponding author: Lejninau@mail.ru 
managing energy systems based not only on traditional generation but also on renewable energy. Such an approach significantly changes the global and regional energy markets and transforms the model of business processes from centralized to distributed.

The use of digital technologies not only leads to a change in the process of interaction between electric companies with consumers but also fundamentally changes the business processes of these companies [10]. The intellectualization of energy systems is growing, new solutions are being developed for the net-metering and net-billing schemes with socalled prosumers, consumers-producers of electricity.

In these conditions, the purpose of applying of smart technologies is to create a modern, adaptive IT infrastructure of regional and city energy grids, optimizing all stages and functions of managing the interconnected processes of generation, consumption and conservation of electric energy at all levels from long-term planning to automatic real-time monitoring.

\subsection{European Union Electricity Market}

Changes in the electricity market in the European Union (EU) are caused by the following factors:

- transition from the third energy package to the fourth energy package [11];

- changes in the global volumes of electricity consumption and generation (with increasing availability of renewable energy sources (RES) in EU, the role of energy consumers as active participants in the energy system increases);

- the widespread introduction of technologies of LEAN generation and consumption;

- introduction of intelligent technologies for centralized management of urban energy systems, including the level of street lighting, heat supply, etc .;

- application of smart technologies during the construction and operation of urban environment facilities (development of smart cities, construction of smart buildings) [12].

One of the important changes is the process of separation of power distribution owners and operators from suppliers, as well as the creation of conditions for deregulated market of the power supply.

The Treaty on European Union and Treaty establishing the European Community of December 13, 2007 (entered into force on December 1, 2009) [13] state the following main goals in the development of energy:

- ensuring the functioning of the energy market,

- ensuring energy security,

- promotion of energy efficiency and energy saving, including the use of renewable energy sources and the development of new types of energy,

- promoting the integration of energy grids

EU countries sign multilateral acts to implement these goals. These documents include decisions and directives of the European Parliament and the Council of the European Union. Until recently, the primary regulating act in the energy sector was Directive 2009/72/EC of the European Parliament and the Council signed on July 13, 2009. This document regards general rules for the domestic electricity market, and declares repeal of Directive 2003/54/EC [14]. It establishes the basic rules for the production, transmission, distribution, and sale of electricity, considering consumer rights protection. It also regulates the principles of organization and functioning of the electricity utilities to increase the competitiveness and integration of electricity markets between EU countries:

-Distinguish of natural monopoly (transmission, transportation) activities from competitive (production, sale).

- Increasing the share of renewable energy sources from $20 \%$ to at least $27 \%$ by the end of the 2030s. 
- Limiting the monopoly of companies owning electricity delivery networks to end consumers and providing greater freedom to electricity suppliers (generating companies and consumers generating electricity based on renewable energy sources).

The main goal of the third energy package is an antimonopoly campaign and control over situations where monopolistic energy supplying companies restrict or block access of competitors to power lines and, accordingly, to end grid users. The state has the right to demand from monopolists up to $50 \%$ of power lines for transferring them to competitors for rent or for sale.

Since 2018 regulatory framework of the electric power industry in the EU has been transited from the third energy package to the fourth. The last documents were adopted in June 2019, but many of these acts are not yet entered into force. Following them, one of the primary regulators in the electric power industry is the European Parliament and Council Directive No. 2019/944 of 06/05/2019. It declares the general rules of the internal electricity market and amends the Directive 2012/27 / EU [15]

The main provisions of the fourth energy package:

-Distinguish of natural monopoly (transmission, transportation) activities from competitive (production, sale). Even though this was indicated in the framework of the third energy package, many EU countries still have regulated electricity supplies [16].

- Decentralization of electricity consumption and generation.

- Increasing the percentage of renewable energy sources from $20 \%$ to at least $32 \%$ by the end of the 2030 [17,18].

Today, the European Union is a world leader in the use of renewable energy sources. By maximizing the use of energy from renewable sources, the EU can ensure that by 2050 more than $80 \%$ of the electricity will come from RES [19].

\subsection{Russian electricity market}

The energy system of Russia consists of the UES of Russia (seven integrated energy systems (UES) - the UES of the Center, the Middle Volga, the Urals, the North-West, the South and Siberia) and the territorially isolated energy systems (Chukotka Autonomous Okrug, Kamchatka Territory, Sakhalin and Magadan Oblast, Norilsk-Taimyr and Nikolaev energy districts, power systems of the northern part of the Republic of Sakha (Yakutia)). Russia has more than 700 power plants, which produced $1,080.6$ billion $\mathrm{kWh}$ of electricity in 2019. Of these, thermal power plants - 63\%, nuclear power plants - $19.32 \%$, hydroelectric power plants $-17.6 \%$ [20].

Russia fully confirms its intention to participate in solving global ecological problems by ratifying the Paris Agreement (Decree of the Government of the Russian Federation of September 21, 2019 No. 1228). It means that green energy is acquiring an increasingly important status in Russia.

The majority of greenhouse gas emissions traditionally come from the energy sector, and its part in 2017 was $78.9 \%$. In 2020 Russia plans to decrease the carbon intensity of its GDP by $9 \%$ comparing with the level of 2017 . And in 2030 by $48 \%$. In particular, electricity production on renewable energy sources will increase by 50 times by 2050 and will reach 55 billion $\mathrm{kWh}$.[21]. Government plans to make renewable energy sources competitive compared to the traditional ones in 2035.

Russia implements the concept of developing 50 smart cities based on the integration of information and communication technologies and the Internet of things. The priority areas are transport, utility infrastructure, energy, industry, and e-government [22]. 


\section{Energy management and energy saving trends in smart cities}

The following intelligent systems are used to manage energy supply in smart cities in world and Russian practice.

\subsection{Renewable energy sources}

Grid Users will be able to produce, store, and sell their energy using renewable energy sources. They also can analyze their consumption profile and market proposals and choose the most optimal energy Supplier. Thus the electricity market gains new properties through the integration of distributed renewable energy sources into the grid.

The European Union was one of the first participants in the clean energy movement. In 2009 , the EU set ambitious goals in the field of energy and climate for 2020 - to reduce greenhouse gas emissions by $20 \%$ and increase renewable energy by $20 \%$ and energy efficiency by $20 \%$ [23]

Thus, we can conclude that Europe has the aim to change the structure of the energy market. The market will have to provide an opportunity for decentralized, eco-friendly, and independent energy production. It will allow more efficient selling of generated electricity to consumers in different regions, provide them clear conditions and required quantities. The share of renewable energy sources in heating and cooling systems will also increase. A significant role should be given to bioenergy.

EU Consumers who produce electricity from renewable energy for their own needs can sell surplus electricity without losing their rights as consumers. A private person will be able to supply up to $10 \mathrm{MW}$, and a legal entity - up to $500 \mathrm{MW}$ without acquiring supplier status [11].

In Russia, a new technological cluster is currently fully formed, which includes the production of equipment, new competencies in the construction and management of renewable energy-based energy facilities. An increase of renewable energy part in the country's energy balance (planned to reach 3\% of the volume of electricity by 2025) stimulates the development and implementation of promising digital technologies in the electric power industry.

The Russian government approved the extension of the renewable energy support program until 2035, including an increase in the capacity of small hydropower plants from $25 \mathrm{MW}$ to $50 \mathrm{MW}$. The total turnover of all renewable energy markets in Russia on the horizon until 2035 is estimated at 2.7 trillion rubles [24].

\subsection{Energy storage systems}

For the stable operation of the energy system with a large amount of renewable energy, it is important to provide balancing power. Electricity storage and storage systems, which are currently being intensively developed, allow changing the basic technological principle matching the level of generation and consumption at a single point in time.

According to the forecasts of Bloomberg New Energy Finance, the global market for energy storage systems (ESS) will grow 122 times by 2040 from the level of 2018. The total installed capacity of ESS will exceed the threshold of $1000 \mathrm{GW}$ [25]. Forecasts of the volumes of the Russian market of energy storage systems until 2030 are 10-15 GW [26].

ESS allows to:

reduce peak loads in the network, align the consumption and generation of electricity; use generator sets of lower power, while optimizing their operation, which significantly reduces fuel consumption and increases the resource of generators;

compensate for reactive power consumed by the load accurately and in real-time mode; 
increase the efficiency of the system with renewable energy-based generating units by accumulating excessively generated energy;

improve the quality of electricity, thanks to the phase-by-phase control of power flows, the possibility of frequency regulation, and the speed of the ESS.

\subsection{SMART - technologies}

To improve energy supplies and carry out activities in the energy market, the main objects of digitalization in the field of electric power have been allocated.

Smart devices that consume electricity. Devices capable to optimize the modes of energy consumption, depending on the system load profile, consumption tariff schemes, and the final requirements for the equipment operation. The end grid user has the opportunity not only to receive and consume electricity but also to produce and transfer it to the network through renewable energy sources.

Smart electricity grids capable of quick self-healing in the event of failure are highly reliable and can manage the load. [27].

Russia begins the construction of an intelligent electric power (capacity) metering system. It includes the installation of smart meters to automatically remotely transmit current readings and the mode of electricity consumption to the energy company, give a signal about an accident in the network, unauthorized interference, and fraud. Such an approach significantly simplifies the work with the elements of the power system and increase their controllability.

With the correct use of these technologies, it is possible to increase the flexibility and adaptability of the power system, reduce losses, smooth out peak loads, and increase using of renewable energy sources in the electric power industry.

A new type of grid user appears on the energy market - prosumer, which can not only consume electricity but also produce for itself or transfer back to the network the energy produced by renewable energy sources. Also, prosumers or prosumers and consumers can aggregate together under the management of any legal authority. It will allow consumers to reduce energy costs, become more independent from the supplier.[28].

\section{Future Energy System Model}

The target energy system model is presented in Fig. 1. Large power plants and RES units generate electricity. This electricity is distributed through power lines between large industrial consumers (which can also generate electricity and send it back to the network) and small industrial consumers, commercial and residential consumers. Until recently, such grid users were only able to generate electricity for their personal purposes, without receiving benefits or discounts from the electricity supplier. Also, they did not have the opportunity to send it back to the network. It is the so-called centralized model of the electricity market.

But now the current situation is changing - the transition to an unregulated market in developed countries has already begun. Russia already had made its first steps: on March 21, 2020, Resolution of the Government of the Russian Federation No. 320 "On amendments to some acts of the Government of the Russian Federation on the functioning of active energy complexes" was adopted [29]. In Fig. 1 shows a distributed energy development model in a dotted box. Decentralization changes the architecture of the energy system: new solutions in the field of electricity production and storage with the simultaneous development of smart grids make it possible to connect more and more distributed devices that transmit electricity to the grid. The fundamental property of all these new technologies is their proximity to the energy consumer. 


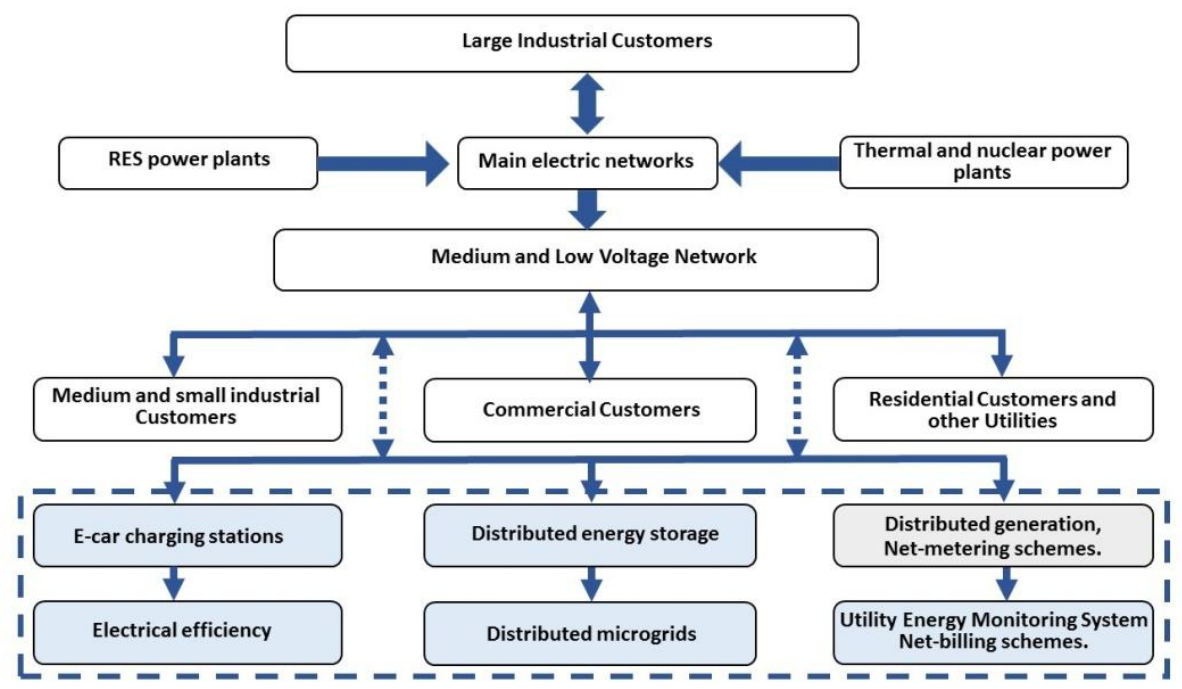

Fig.1. Model of the development of a power system from centralized to distributed.

Current trends in the development of the electric power industry have many advantages for end-users. They have opportunities:

- selection of any Supplier from those presented on the market with the most acceptable conditions for the sale of electricity, which affects the client's consumption and using more flexible schemes of tariff zones;

- replacing the old scalar meters with smart-meters of the new generation. Such meter can independently send indications and messages about malfunctions to the service company or sales company;

- self-generation of electricity using renewable energy for personal use or with the return to the network.

The transition from a centralized model of the electricity market to a distributed one entails changes in the computer-aids. It stresses the needs in the construction of information systems with new functional capabilities.

\section{Digitalization of the business processes of the distribution organization in the electricity market}

Electric power systems built according to the traditional, centralized architecture have by now almost completely exhausted their efficiency resource. The transformation of the country's energy system from centralized to decentralized leads to a high level of competition in the electricity market and a large number of market players with dedicated and mixed functions (generation, supply, storage and consumption of electricity) and various forms of contractual relations, both among themselves and distribution organization. To this end, a particular body shall be formed to regulate the market. It can be the market operator or the transition network operator responsible for pricing and determining the amount of electricity supplied both throughout the market and in the context of sales organizations.

It should be minded that for regional distribution organizations this means changing and redefining business processes and the software used.

To meet the separation of electricity supply and distribution activities from electricity distribution activities, we can propose the following minimum set of business functions that should be supported by the software of the distribution organization (Table 1). 
Table 1. Functional composition of the distribution system software complex

\begin{tabular}{|c|c|}
\hline $\begin{array}{c}\text { Stage } \\
\end{array}$ & Functionality \\
\hline $\begin{array}{l}\text { Meter Purchase } \\
\text { and warehousing }\end{array}$ & $\begin{array}{ll}\text { - } & \text { Meter Purchase } \\
\text { - } & \text { Meter Storage and Stock movement } \\
\text { - } & \text { Inspection, verification and calibration of meters } \\
\text { - } & \text { Meter vending } \\
\text { - } & \text { Different lifecycles for smart and manual meters }\end{array}$ \\
\hline $\begin{array}{l}\text { Supply Point } \\
\text { Technical } \\
\text { Connection }\end{array}$ & $\begin{array}{ll}\text { - } & \text { Technical Connection service orders management } \\
\text { - } & \text { Technical Connection field activities management } \\
\text { - } & \text { Technical Inspection field activities management } \\
\text { - } & \text { Contact with the service order applicants } \\
\text { - } \quad \text { Installation } \backslash \text { ReplacinglDeinstallation of meters }\end{array}$ \\
\hline $\begin{array}{l}\text { Integration with } \\
\text { external systems }\end{array}$ & $\begin{array}{ll} & \text { SCADA } \\
\text { - } & \text { GIS } \\
\text { - } & \text { Meter head-end system OR } \\
\text { - } & \text { Meter reading orders system (managing of cycles and routes for } \\
& \text { metering, mobile app, etc) } \\
\text { - } & \text { Billing system (both for chargeable field activities and consumption } \\
& \text { volumes) } \\
\text { - } & \text { Reporting System (both for operative and analytical reports) } \\
\text { - } & \text { etc }\end{array}$ \\
\hline Meter Readings & $\begin{array}{ll}\text { - } & \text { Maintaining of scalar and interval readings } \\
\text { - } & \text { Manage of reading cycles and routes } \\
\text { - } & \text { Auto } \backslash \text { Validation and estimation of readings } \\
\text { - } & \text { Finalization of readings } \\
\text { - } & \text { Calculation of planned consumption } \backslash \text { generation volumes } \\
\text { - } & \text { Calculation of planned and emergency losses } \\
\text { - } & \text { Aggregation and fraud detection }\end{array}$ \\
\hline Meter Events & $\begin{array}{ll} & \text { Monitoring of meter events from smart-meters } \\
- & \text { Incident management } \\
- & \text { Outage events } \\
\text { - } & \text { Fraud events and activities } \\
\end{array}$ \\
\hline Load balancing & $\begin{array}{l}\text { - Selective and mass load shedding } \\
\text { - Load Management on base of known load profiles for different } \\
\text { categories of clients } \\
\text { - Load Management for city resources (lighting, heating, irrigation, } \\
\text { etc) } \\
\text { - Predictive models for load profiling }\end{array}$ \\
\hline $\begin{array}{l}\text { Communication } \\
\text { with Suppliers and } \\
\text { Market Operators }\end{array}$ & $\begin{array}{l}\text { - Calculation of billing determinants (volumes of consumption, } \\
\text { generation) for end-users and different levelslcategories of } \\
\text { userslsupply points } \\
\text { - Aggregation of consumption and generation volumes for different } \\
\text { levels of the electric grid } \\
\text { - Aggregation of technical and commercial losses in the electric grid } \\
\text { - Scalar and interval models of supply profile for different categories } \\
\text { of clients }\end{array}$ \\
\hline
\end{tabular}

It should be noted that the distribution organization is additionally responsible for the implementation of the last two business blocks: data transmission to suppliers and communication with the market operator and the transmission operator. 
This market trend also means that in most scenarios, distribution organization, not the suppliers, is responsible for the centralized collection of data for all market participants and grid users for the subsequent processing and transfer of aggregated data to the level of the market or transmission operator.

It also means that in most cases, the distribution and sales organization will have separated client contacts databases, which in some way should be synchronized, at least in the direction from the supplier organization to the distribution organization.

Taking in account the requirements for the protection of personal data and privacy in the European Union [30], the organization of this kind of data exchange can be a difficult process not only from a technical but also from a legal point of view.

In 2020, Russia will also determine the rules for the operation of distributed energy entities (active energy complexes) on the following issues: contractual relations in the wholesale and retail electricity markets; pricing and tariff setting; technological connection to the public network; technological and informational interaction of the active energy complex with the UES of Russia [31].

It should be borne in mind that the software of suppliers must also be redefined appropriately and at the same time, this requirement should not discriminate between the sales organization and other market players, including in comparison with the supervising \leading supplier.

This leads to the need for the distribution organization to develop a universal connector or portal solution for connecting information systems (IS) of various suppliers, or to ensure data transfer in a way that would not infringe on the interests of the supplier.

Also, one should not forget that in most cases there is no software for distributed private electricity generators (prosumers), which means that the distribution organization should most likely provide resources for maintaining generation data, taking into account its role as a reporting body to the market operator and the transmission operator.

\section{Conclusions}

A comparative analysis of trends in the development of the electricity market in the European Union and Russia allowed us to identify the main areas of development:

- transition to an unregulated electricity market;

- widespread use of renewable energy sources;

- mass replacement of scalar metering devices with interval ones;

- the emergence of energy storage facilities;

- the emergence of consumers capable to generate and store electricity.

This leads to a transition from a centralized model to a distributed model of the energy system, which in turn leads to a change in the role of distribution organizations in the electricity market and requires the development of a separate class of software aimed at the needs of the distribution organization, taking into account its role as a mediator between the market operator and / or transmission operator and other grid users: sales organizations, private organizations for energy generation, aggregators of metering points, etc.

\section{References}

1. Passport of the national program "Digital Economy of the Russian Federation", http://government.ru/info/35568/

2. A.Caragliu, C.DelBo,P.Nijkamp, Journal of Urban Technology,18 (2011)

3. G. Rzevski, P.Skobelev,Managing Complexity(2014) 
4. A.Meijer, R.Gil-Garcia, M.P.R. Bolivar, Social Science Computer Review, 34, 6 (2015)

5. A.Meijer, M.P.R. Bolivar, International Review of Administrative Sciences, 82 (2016)

6. L.Gitelman, M. Kozhevnikov, Economy of Region,4 (2017)

7. C.F. Calvillo, A. Sánchez-Miralles, J.Villar, Renewable and Sustainable Energy Reviews,55 (2016)

8. R. Barelkowski, International Journal of Energy Production and Management, 1 (2016)

9. Y. Nurulin, I. Skvortsova, O.Kalchenko, SHS Web of Conferences,61 (2019)

10. The Future of Power Utilities in Central and Eastern Europe (2016),https://www.pwc.com/

11. Clean Energy For All Europeans, https://op.europa.eu/

12. V. Kupriyanovsky, F.Fokin, S.Bulancha, Yu.Kupriyanovskaya, D. Namiot, International Journal of Open Information Technologies, 4 (2016)

13. Treaty of Lisbon amending the Treaty on the European Union and the Treaty establishing the European Community, 306 (2007), https://www.refworld.org/

14. Directive EC of the European Parliament and of the Council, July 13, 2009 regarding the general rules for the domestic electricity market and the repeal of Directive, (2009)https://eur-lex.europa.eu/

15. Directive (EU) 2019/944 of the European Parliament and of the Council of 5 June 2019 on common rules for the internal market for electricity and amending Directive 2012/27/EU (2019), https://op.europa.eu/

16. D.Ispolinov, T.Dvadtsatova, J. Baltic region, 2 (2013)

17. European Commission (2019), https://ec.europa.eu/

18. European Commission, (2019), https://ec.europa.eu/

19. Clean Energy for all Europeans (2019), https://op.europa.eu/

20. Ministry of Energy of the Russian Federation (2019), https://minenergo.gov.ru

21. Long-term development strategy of the Russian Federation with a low level of greenhouse gas emissions until 2050 (2019), https://economy.gov.ru/

22. I. Drozdova, A.Petrov, SHS Web of Conferences, 44, 00031 (2018)

23. Clean energy for all Europeans package completed: good for consumers, good for growth and jobs, and good for the planet (2019), https://ec.europa.eu/

24. The turnover of renewable energy markets by 2035 is estimated at 2.7 trillion rubles, (2019), https://peretok.ru/news/worldenergy/21499/

25. Energy Storage Investments Boom As Battery Costs Halve in the Next Decade (2019),https://about.bnef.com/

26. The use of energy storage systems in Russia: opportunities and barriers (expert analysis report) (2019), https://energynet.ru/

27. Energy Forecast for the World and Russia 2019, 54 (2019)

28. G.Ermolenko,European Union Renewable Energy Handbook(2016)

29. Decree of the Government of the Russian Federation of March 21, 2020 No. 320 "On Amending Certain Acts of the Government of the Russian Federation on the Functioning of Active Energy Complexes" (2020),http://publication.pravo.gov.ru/

30. General Data Protection Regulation, https://gdpr-info.eu/ 
31. Decree of the Government of the Russian Federation of April 28, 2018 N 830-r On approval of the action plan ("road map") to improve legislation and remove administrative barriers in order to ensure the implementation of the National Technology Initiative in the "Energy" direction,http://government.ru/docs/32548/ 